\title{
SUMMER HEAT AND ICE BALANCES ON HODGES GLACIER, SOUTH GEORGIA, FALKLAND ISLANDS DEPENDENCIES
}

\author{
By I. G. G. HogG*, J. G. PAren, and R. J. Timmis \\ (British Antarctic Survey, Natural Environment Research Council, Madingley Road, Cambridge \\ CB3 0ET, England)
}

\begin{abstract}
Aвstract. The heat and ice balances of a temperate sub-Antarctic cirque glacier were measured through the 1973-74 melt season at an altitude midway between the climatic firn limit and the snout. The melt calculated from mean daily measurements at a single level of net radiation, wind-speed, temperature, and humidity agreed with that observed at nearby budget stakes. In the central ablation zone, radiation provided $(54 \pm 6) \%$ and sensible fluxes $(46 \pm 6) \%$ of the heat income through the summer, which was exceptionally warm and sunny. Latent-heat fluxes made no significant contribution to the heat balance. The calculation by Smith (1960) that the radiative, sensible, and latent heat fluxes contribute about equally to ablation in this zone has not been substantiated by measurement. The measured partition of the glacier's heat balance suggested that maritime influences on its regime are mitigated by its position in the lee of a major mountain range.
\end{abstract}

RÉsumé. Bilans de chaleur estivale et de glace sur le Hodges Glacier, South Georgia, Falkland Islands Dependencies. On a mesuré au cours de la saison de fusion 1973-74, les bilans thermiques et glaciaires d'un glacier de cirque tempéré sub-Antarctique à une altitude à mi-chemin entre la ligne de névé climatique et le front. La fusion, calculée à partir des moyennes de mesures journalières, à un même niveau, du bilan radiatif net, de la vitesse du vent, de la température et de l'humidité, est en bon accord avec les observations près des balises. Dans la zone d'ablation centrale, le rayonnement représente $(54 \pm 6) \%$ et la chaleur sensible $(46 \pm 6) \%$ des apports énergétiques au cours de l'été qui a été exceptionnellement chaud et ensoleillé. Les flux de chaleur latente ne contribuent pas significativement au bilan thermique. Le calcul de Smith (1960) selon lequel les flux de chaleur rayonnée, sensible et latente contribuent à peut près également à l'ablation dans cette zone n'a pas été confirmé par les mesures. La répartition qui a été mesurée entre les facteurs du bilan thermique du glacier fait supposer que les influences maritimes sur son régime sont tempérées par sa position sous le vent d'une haute chaine de montagne.

Zusammenfassung. Sommerliche Wärme- und Massenbilanz am Hodges Glacier, South Georgia, Falkland Islands Dependencies. An einem subantarktischen temperierten Kar-Gletscher wurde in der Schmelzperiode 1973/74 die Wärme- und Massenbilanz auf halber Höhe zwischen klimatischer Firnlinie und Zunge gemessen. Der Schmelzabtrag, berechnet aus gemessenen Tagesmitteln von Netto-Einstrahlung, Windgeschwindigkeit, Temperatur und Feuchtigkeit, stimmte gut mit den Beobachtungen an nahegelegenen Ablationspegeln überein. In der Hauptablationszone lieferten die Strahlung $(54 \pm 6) \%$ und der fühlbare Wärmefluss $(46 \pm 6) \%$ der Wärmeaufnahme während eines ungewöhnlich warmen und sonnigen Sommers. Der latente Wärmefluss trug nicht wesentlich zum Wärmehaushalt bei. Die Berechnung von Smith (1960), wonach Strahlung, fühlbare und latente Wärme etwa gleichviel Ablation in dieser Zone bewirken, wurde durch die Messung nicht bestätigt. Die gemessene Aufteilung der Wärmebilanz des Gletschers lässt annehmen, dass maritime Einflüsse auf seinen Haushalt durch seine Lage im Lee einer grösseren Bergkette germildert werden.

\section{INTRODUCTION}

South Georgia is a mountainous sub-Antarctic island lying $2000 \mathrm{~km}$ east of Drake Passage between South America and Antarctica. Permanent ice covers $58 \%$ of the island which is about $170 \mathrm{~km}$ long, up to $32 \mathrm{~km}$ wide, and whose highest point is Mt Paget, $2934 \mathrm{~m}$ (Fig. 1). Its relief is dominated by the Allardyce and Salvesen ranges which are about $2000 \mathrm{~m}$ high and run in a north-west to south-east direction across the prevailing westerly wind. Many cirque and valley

* Present address: Sir M. MacDonald and Partners, Station Road, Cambridge CB1 2RS, England. 

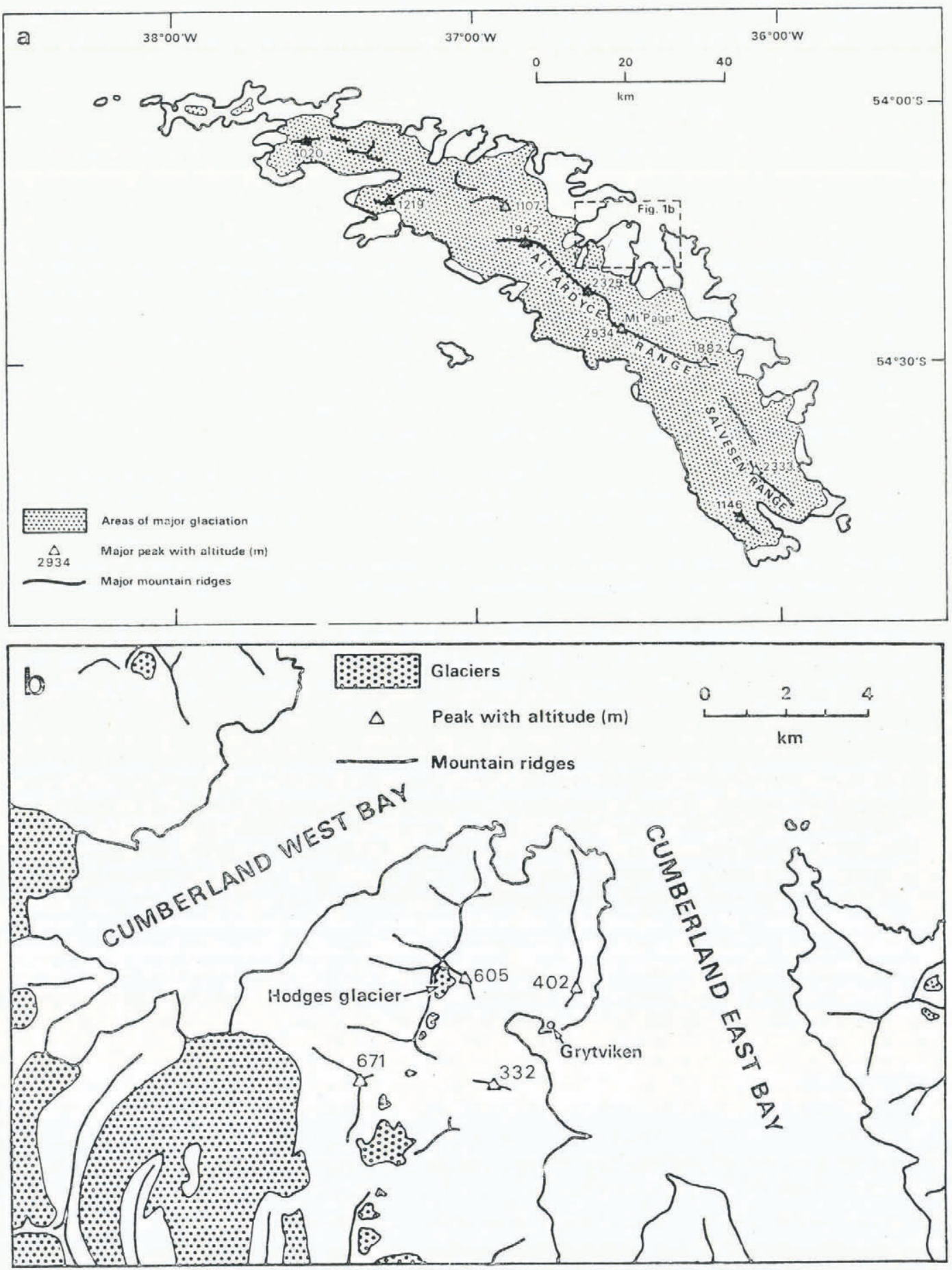

Fig. 1. (a) Map of South Georgia. (b) Location of Hodges Glacier. 
glaciers flow from accumulation basins cut deep in the mountains. Studies of glacier regimes in South Georgia can further understanding of the sub-Antarctic climate and of the variation of glacier characteristics with latitude and continentality. This study was made on Hodges Glacier, a small cirque glacier at lat. $54^{\circ} 16^{\prime} \mathrm{S}$., long. $36^{\circ} 32^{\prime} \mathrm{W}$. The glacier is a vestigial ice mass lying on the relatively ice-free peninsula between Cumberland West Bay and Cumberland East Bay and within the precipitation shadow of the Allardyce Range. It had an area of $0.234 \mathrm{~km}^{2}$ in 1974 and its altitude ranged from $303 \mathrm{~m}$ to $615 \mathrm{~m}$ (Fig. 2). Its surface had a mean slope of $25^{\circ}$ and a mean aspect of $144^{\circ}$ east of north.

Hodges Glacier was mapped by the British South Georgia Expedition 1954-55 (Sutton, 1957) and its climate and mass budget were first studied during the International Geophysical Year 1957-58 (Stansbury, unpublished; Smith, 1960). In November 1971, the British Antarctic Survey and the Institute of Hydrology began a joint investigation of the heat, ice, and water balances of the glacier and its basin. This paper compares the melt calculated from meteorological measurements in the middle of the glacier ablation zone with that observed at neighbouring budget stakes during the entire melt season of 1973-74.

\section{Climatic background}

South Georgia has a cool, windy, and damp climate, owing to its position south of the Antarctic Convergence and within the cyclonic westerlies of the maritime sub-Antarctic. On the north-east coast the mean winter (April-October) temperature is typically $+0.4{ }^{\circ} \mathrm{C}$ and minima seldom fall below $-10^{\circ} \mathrm{C}$. Although winter precipitation exhibits large interannual variability, in 1973 it was close to the average for $1965-73$ with $1169 \mathrm{~mm}$ recorded at Grytviken. Summers are generally moist with an average precipitation of $661 \mathrm{~mm}$, approximately half of which falls as rain. The mean temperature (November-March) is typically $+4.5^{\circ} \mathrm{C}$ although maxima can rise above $+20^{\circ} \mathrm{C}$ during föhn winds. These are a striking feature of the South Georgia climate and are usually associated with intrusions of transitional tropical maritime air (Mansfield and Glassey, 1957, p. 17). Table I summarizes meteorological data from summers in the period 1965-74 and shows that the summer of 1973-74 was significantly warmer than average with reduced cloud cover and less wind (British Antarctic Survey Meteorological Service, unpublished; Limbert and Loan, 1976[a], [b]; Limbert, 1977[a], [b]).

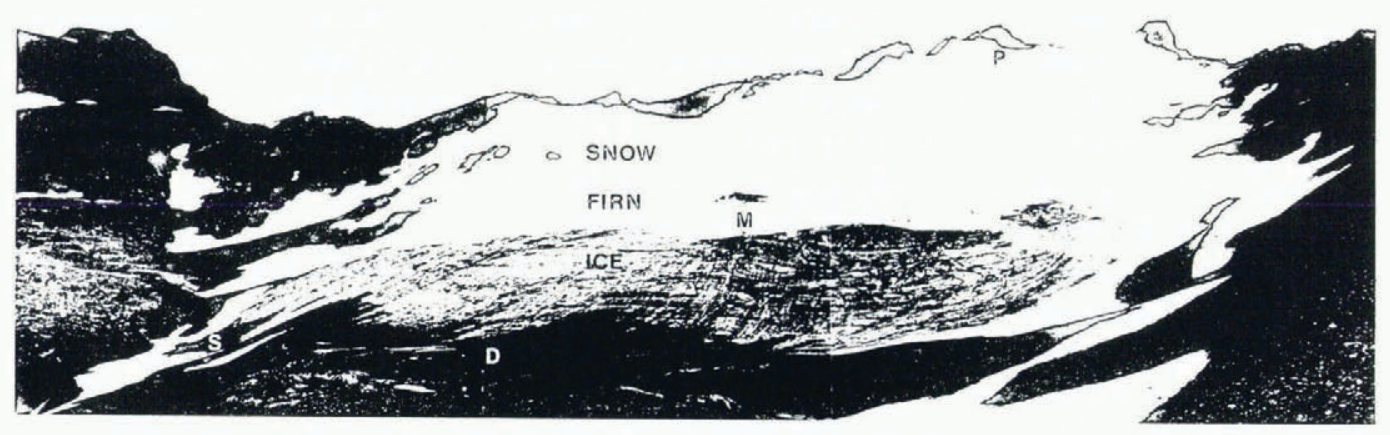

Fig. 2. Hodges Glacier, I February 1974. P is Petrel Peak (635 m). M is the meteorological site (375 $\mathrm{m}) . \mathrm{S}$ is the lowest lobe of the glacier snout $(303 \mathrm{~m}) . \mathrm{D}$ is the position of the Dines rain gauge. 
Table I. Summer meteorological data from Grytviken, South Georgia

\begin{tabular}{|c|c|c|c|c|c|}
\hline \multirow[b]{2}{*}{ Years } & \multicolumn{4}{|c|}{ November-March inclusive } & \multirow[b]{2}{*}{$\begin{array}{c}\text { Total } \\
\text { precipitation } \\
\mathrm{mm}\end{array}$} \\
\hline & $\begin{array}{c}\text { Mean air } \\
\text { temperature } \\
{ }^{\circ} \mathrm{C}\end{array}$ & $\begin{array}{c}\text { Mean water- } \\
\text { vapour pressure } \\
\text { mbar }\end{array}$ & $\begin{array}{l}\text { Mean wind } \\
\text { speed } \\
\mathrm{m} \mathrm{s}^{-1}\end{array}$ & $\begin{array}{c}\text { Mean cloud } \\
\text { cover } \\
\text { oktas }\end{array}$ & \\
\hline $1965-66$ & 4.9 & 6.1 & 4.9 & 5.8 & 582 \\
\hline $1966-67$ & 3.2 & 5.7 & 5.0 & 6.1 & 609 \\
\hline $1967-68$ & 4.6 & 6.1 & 4.1 & 5.9 & 693 \\
\hline $1968-69$ & 4.2 & 6.6 & 4.1 & 6.1 & 966 \\
\hline $1969-70$ & 4.4 & 5.6 & 5.3 & 6.1 & 657 \\
\hline $1970-71$ & 4.9 & 6.2 & 4.0 & 6.0 & 712 \\
\hline $1971-72$ & 4.2 & 5.9 & 4.5 & 6.1 & 749 \\
\hline $1972-73$ & 4.3 & 5.9 & 4.3 & 5.9 & $322^{*}$ \\
\hline $1973-74$ & 5.6 & 6.2 & 3.9 & 5.4 & 623 \\
\hline Average & 4.5 & 6.0 & 4.5 & 5.9 & 657 \\
\hline $\begin{array}{l}\text { Standard } \\
\text { Deviation }\end{array}$ & 0.7 & 0.3 & 0.5 & 0.2 & 169 \\
\hline
\end{tabular}

Figure 3 shows the weekly precipitation and seven-day running means of meteorological variables at Hodges Glacier during the summer of 1973-74. High temperatures persisted from late January to March 1974 (mean $>+5^{\circ} \mathrm{C}$ ) with the highest occurring during föhn winds. Precipitation amounted to $501 \mathrm{~mm}$ for the summer with snow predominating during November, December, and early January. Most precipitation fell as rain during the second half of the summer and was concentrated in heavy falls near the beginning of each month.

\section{INSTRUMENTATION}

The meteorological site (Fig. 2) was located at $375 \mathrm{~m}$ midway between the snout of the glacier and the climatic firn limit at $460 \mathrm{~m}$ (Smith, 1960). The mean slope at the site was $15^{\circ}$ with an aspect of $140^{\circ} \mathrm{E}$. Global and reflected short-wave radiation were measured with Moll-Gorzynski solarimeters and net radiation was measured by a Funk radiometer. All the radiation sensors were mounted horizontally. The air temperature sensor was an aspirated and shielded platinum resistance thermometer, and water-vapour pressure was calculated from measurements of dew point made with a lithium chloride dew-cell. A Porton Down cup anemometer was used to measure wind-speed. The instruments were all maintained at $1.0 \pm 0.1 \mathrm{~m}$ above the glacier surface and measurements were recorded every $72 \mathrm{~s}$ on a multichannel chart recorder. At times when faults caused incomplete records, missing values were generated by simple regressions between meteorological variables measured on the glacier and those observed at the Grytviken meteorological station $2.4 \mathrm{~km}$ away (Fig. 1). Approximately $20 \%$ of the data were so derived. In addition to the meteorological sensors, a string of platinum resistance thermometers measured englacial ice temperatures to a depth of $10 \mathrm{~m}$.

Changes in ice storage were calculated from periodic measurements at an array of eight vertical stakes and two snow-density pits around the meteorological site. The array covered an area of $0.02 \mathrm{~km}^{2}$ and ranged from $372 \mathrm{~m}$ to $413 \mathrm{~m}$ above sea-level with a mean altitude of $390 \mathrm{~m}$. The stakes were measured on 16 occasions during the period 1 November 1973 to 4 April 1974 at intervals of between 6 and 21 d. Precipitation was recorded in front of the glacier 

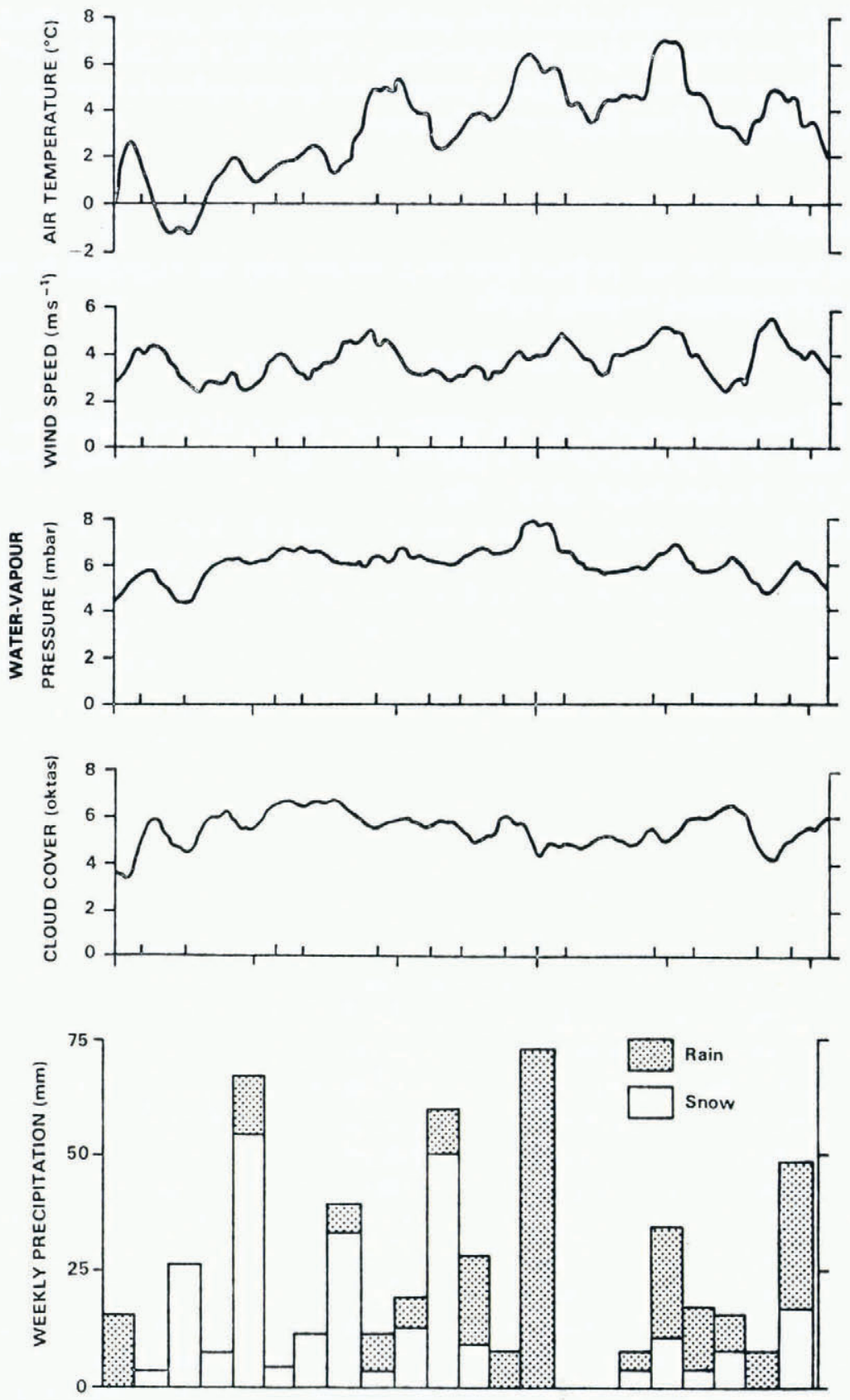

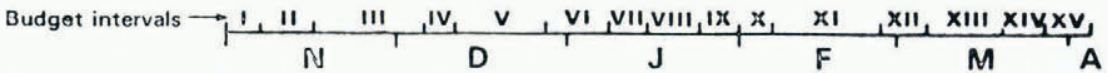

Fig. 3. Weekly precipitation and seven-day running means of meteorological variables at the meteorological site, Hodges Glacier, 1 November 1973 to 4 April 1974. Air temperature, wind-speed, and water-vapour pressure were measured I $m$ above the glacier surface. 
snout (Fig. 2) by a Dines tilting-siphon rain gauge. Although the gauge was shielded by a $3 \mathrm{~m}$ diameter pit ([World Meteorological Organization], 1970, p. II.2), its catch was still reduced by strong winds. A comparison with adjacent ground-level gauges indicated errors of up to $20 \%$ in the snow collected by the Dines gauge on windy days.

\section{THE HEAT BALANCE}

The heat balance of the surface layer of a glacier may be expressed in the form (cf. [International Hydrological Decade], 1970)

$$
F_{\mathrm{r}}+F_{\mathrm{h}}+F_{1}+F_{\mathrm{p}}+F_{\mathrm{f}}=F_{\mathrm{m}}+F_{\mathrm{s}},
$$

where $F_{\mathrm{r}}$ is the radiative heat flux, $F_{\mathrm{h}}$ the sensible heat flux, $F_{1}$ the latent-heat flux, $F_{\mathrm{m}}$ the heat available to melt ice, $F_{\mathrm{s}}$ the change in sensible heat storage, $F_{\mathrm{f}}$ the heat contributed by freezing water, and $F_{\mathrm{p}}$ the heat contributed by precipitation.

The englacial temperatures of Hodges Glacier varied little from the melting point during summer. Consequently, the sensible heat storage remained unchanged and $F_{\mathrm{s}}$ was effectively zero (except for very short periods such as occasional overnight freezing). Under these temperature conditions, $F_{\mathrm{f}}$ must also have been negligible. Air temperatures were typically within $2 \mathrm{deg}$ of the melting point during both rain and snow falls, each of which accounted for about half the summer precipitation. Thus $F_{\mathrm{p}}$ was effectively negligible, providing less than $1 \%$ of the total summer heat flux. With these simplifications the heat balance equation may be approximated by

$$
F_{\mathrm{r}}+F_{\mathrm{h}}+F_{1}=F_{\mathrm{m}}
$$

\section{The radiative heat flux}

The International Association of Scientific Hydrology has recommended that comparison of a glacier's heat and ice budgets be made over unit area of its horizontally projected surface ([International Hydrological Decade], 1970, p. 13). The radiative heat flux to a level glacier is then simply the measured net radiation, whose components need not be resolved. This simplicity does not extend to sloping glaciers where the contributions of long-wave, direct short-wave, and diffuse short-wave radiation must each be resolved and adjusted to the horizontally-projected surface. Kondratyev (1969) has shown that the flux of isotropic sky radiation on a shallow slope $\left(<30^{\circ}\right)$ is approximately equal to that on a horizontal surface reduced by the cosine of the slope angle. The horizontal projection of the slope has an area equal to the slope's area reduced by the same factor. Thus the flux of isotropic radiation on a horizontal radiometer at the Hodges Glacier site was effectively that on a horizontal projection of its shallow $\left(15^{\circ}\right)$ slope. This approximate result was used to adjust for slope the reflected short-wave, diffuse short-wave, and net long-wave radiations, all of which were assumed isotropic and measured by horizontal sensors. The reflected short-wave radiation was measured directly at the glacier; the diffuse short-wave radiation was not measured in situ but instead was obtained from a horizontal radiometer at the Grytviken meteorological station. The Grytviken measurements were applied directly to the glacier because skyline plots showed similar topographic screening at both sites. In addition, they usually experienced the same cloudiness and the effect of their altitude difference was negligible in comparison with the accuracy of the radiometer measurements. The 
net long-wave radiation was obtained as a residual in the radiation balance. The approximations employed for isotropic radiations (i.e. Kondratyev's method and the transposition of diffuse short-wave radiation from Grytviken) were justified because the radiations were required only for slope adjustment of net radiation measured in situ over a shallow gradient.

The treatment of the direct solar beam is more complicated. To simplify the problem we first consider the instantaneous radiation geometry where the radiation components and angles are as defined in Table II.

On unit area of a horizontal sensor the instantaneous flux is

$$
S_{\mathrm{i}}^{\prime}=I(\theta) \cos \theta .
$$

The flux required for comparison with vertical changes in ice storage is the flux per unit of horizontally projected area given by

$$
S_{\mathrm{i}}=I(\theta) \cos \theta^{\prime} / \cos \eta=S_{\mathrm{i}}^{\prime} \cos \theta^{\prime} / \cos \theta \cos \eta .
$$

Because $L^{\prime}, S_{\mathrm{d}}^{\prime}$, and $S_{\mathrm{o}}^{\prime}$ are assumed isotropic, the instantaneous short-wave radiation flux per unit of horizontally projected area is:

$$
S_{\mathrm{g}}=S_{\mathrm{i}}+S_{\mathrm{d}}^{\prime}
$$

and the instantaneous net radiation flux on the projection is:

$$
F_{\mathrm{r}}=S_{\mathrm{i}}+S_{\mathrm{d}}^{\prime}-S_{\mathrm{o}}^{\prime}+L^{\prime} .
$$

TABLE II. SYMBOLS USED FOR RADIATION COMPONENTS AND ANGLES

\section{Radiation}

Incoming direct

short-wave

Incoming diffuse

short-wave

Incoming diffuse and

direct short-wave

Reflected diffuse and direct short-wave

Net long-wave

radiation

Net radiation

\section{Angles}

Angle of slope from the horizontal

Solar zenith angle

Angle between the direct beam and the normal to the slope per unit area

of horizontal glacier

$S_{\mathrm{i}}$

$S_{\mathrm{d}}^{\prime}$

$S_{\mathrm{g}}^{\prime}$

$S_{\circ}^{\prime}$

$L^{\prime}$

$F_{\mathrm{r}}^{\prime}$

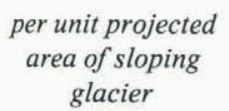

$S_{\mathrm{i}}$

$S_{\mathrm{d}}$

$S_{\mathrm{g}}$

$S_{\text {o }}$

$L$

$F_{\mathrm{r}}$

\section{Remarks}

irradiance of the direct beam on a surface at normal incidence $=I(\theta)$.

$S_{\mathrm{d}}^{\prime}$ measured at Grytviken. $S_{\mathrm{d}}=S_{\mathrm{d}}^{\prime}$ for isotropic radiations.

$S_{\mathrm{g}}^{\prime}$ measured by horizontal sensor at Hodges Glacier. $S_{\mathrm{o}}=S_{\mathrm{o}}^{\prime}$ for isotropic radiations.

$L=L^{\prime}$ for isotropic radiations.

$F_{\mathrm{r}}^{\prime}$ measured by horizontal sensor at Hodges Glacier. 
From this treatment we obtain the components of radiative heat flux to be

$$
S_{\mathrm{g}}=\left(S_{\mathrm{g}}^{\prime}-S_{\mathrm{d}}^{\prime}\right) \cos \theta^{\prime} / \cos \theta \cos \eta+S_{\mathrm{d}}^{\prime}
$$

and

$$
F_{\mathrm{r}}=F_{\mathrm{r}}^{\prime}-\left(S_{\mathrm{g}}^{\prime}-S_{\mathrm{d}}^{\prime}\right)\left(1-\cos \theta^{\prime} / \cos \theta \cos \eta\right) .
$$

Garnier and Ohmura (1968) developed a method for calculating the magnitude of $I(\theta) \cos \theta^{\prime}$ for any latitude, date, time, slope angle, and aspect, using accepted values of the solar constant and assuming a power-law absorption of radiation in the atmosphere. Their method allows the calculation of a factor $\alpha$ by which the direct insolation on a horizontal surface at the meterological site is reduced by inclining it parallel to the glacier surface. Mean daily values of $\alpha$ were determined throughout the summer and were used to convert the direct insolation on a horizontal sensor to that on unit area of sloping glacier. This conversion, calculated for cloudless conditions, also applied for days during which sunshine was evenly distributed. during the summer of 1973-74 one of these criteria was generally satisfied at Hodges Glacier. However, during January and February, there was a 2:1 bias of sunshine towards the afternoons; such asymmetry was accounted for by a factor $n$ in the radiation formulae.

The daily short-wave radiation flux $S_{\mathrm{g}}$, and the daily net all-wave radiation flux on a horizontal projection of the glacier $\left(F_{\mathrm{r}}\right)$ were calculated with daily measurements from horizontal sensors by

$$
S_{\mathrm{g}}=\left(S_{\mathrm{g}}^{\prime}-S_{\mathrm{d}}^{\prime}\right) \frac{n \alpha}{\cos \eta}+S_{\mathrm{d}}^{\prime}
$$

and

$$
F_{\mathrm{r}}=F_{\mathrm{r}}^{\prime}-\left(S_{\mathrm{g}}^{\prime}-S_{\mathrm{d}}^{\prime}\right)(1-n \alpha / \cos \eta)
$$

where $n=1$ for days of uniform cloudiness.

The global short-wave component $S_{\mathrm{g}}^{\prime}$ was measured with a possible error of $5 \%$. The uncertainty in diffuse short-wave radiation $S_{\mathrm{d}}^{\prime}$ (transposed from Grytviken) was estimated to be $10 \%$. The specified precision of the Funk net radiometer was $5 \%$ but Latimer (1963) has shown that a carefully maintained Funk radiometer is accurate to between $5 \%$ and $10 \%$. The reliability of radiation measurements from Hodges Glacier was tested by comparing net long-wave radiation deduced from the algebraic sum of $F_{\mathrm{r}}^{\prime}, S_{\mathrm{o}}^{\prime}$, and $S_{\mathrm{g}}^{\prime}$ with values calculated from an empirical formula compiled by Williams (1974). This incorporates the Swinbank counterradiation formula with the local temperature gradient, the amount and type of cloud cover, and the surface slope. The agreement between totals summed over a four-month period was within $6 \%$ indicating good long-term reliability of the radiation measurements. This supports the stated instrumental accuracies which led to likely errors of $5 \%$ and $15 \%$ in the summer totals of global short-wave radiation and net radiation, respectively.

\section{The sensible- and latent-heat fluxes}

Fluxes of sensible and latent heat were calculated from aerodynamic estimates of the heat and water vapour transferred by vertical eddy diffusion in turbulent air over the glacier. The fluxes were assumed proportional to the vertical gradients of temperature and water-vapour 
pressure, and to the rates at which eddies of heat and vapour were transferred vertically (Paterson, 1969, p. 50-51):

$$
\begin{aligned}
& \text { Sensible heat flux, } F_{\mathrm{h}}=C_{p} \rho A_{\mathrm{h}} \frac{\partial T}{\partial z} \\
& \text { Latent-heat flux, } F_{1}=\frac{L M}{R T} A_{1} \frac{\partial e}{\partial z},
\end{aligned}
$$

where $A_{\mathrm{h}}$ is the eddy diffusivity for heat, $A_{1}$ the eddy diffusivity for water vapour, $T$ the temperature of air, $e$ the water-vapour pressure, $C_{p}$ the specific heat of air at constant pressure, $\rho$ the density of air, $M$ the molecular weight of water, $R$ the universal gas constant, $L$ the latent heat of vaporization of water, and $z$ the height. Equation (3) applies strictly to potential temperatures but we used ambient values since, during summer, the temperature lapse between the thermometer and the glacier surface was generally much greater than the adiabatic lapse.

The fluxes of sensible and latent heat were paralleled by the turbulent transfer of momentum represented by $\tau$, the shearing stress of wind on the glacier surface. This was assumed to be proportional to the vertical gradient of wind-speed and the rate at which eddies of momentum were transferred vertically (Paterson, 1969, p. 51):

$$
\tau=A_{\mathrm{m}} \frac{\partial u}{\partial z}
$$

where $u$ is the wind-speed and $A_{\mathrm{m}}$ is the eddy diffusivity for momentum.

The fluxes of sensible heat, latent heat, and momentum are conserved with height in air moving steadily without advection across a homogeneous surface (Sellers, [ $\left.{ }^{\mathrm{c}} 1965\right]$, p. 124-25, 142). In this situation, the eddy diffusivities for heat, water vapour, and momentum can be compared through observed profiles of $T, e$, and $u$. Published profiles suggest that the diffusivities are approximately equal at a given level in neutrally buoyant air over ice (Paterson, 1969, p. 49-54; Holmgren, 1971). Such air is characterized by logarithmic profiles of temperature, water-vapour pressure and wind-speed (see also Grainger and Lister, 1966). Glaciologists commonly assume equal diffusivities in near-neutral and mildly stable stratifications where approximately logarithmic profiles prevail (Gilbert and others, 1969; Williams, 1974; Martin, 1975).

Wind profiles at the meteorological site were studied on $17 \mathrm{~d}$ during December 1973 and January 1974. During this period the upward movement of the temporary snow-line exposed firn surfaces above the site and ice surfaces below it. The mean daily values of wind-speed recorded at $2.8 \mathrm{~m}, 1.0 \mathrm{~m}$, and $0.2 \mathrm{~m}$ were plotted against the logarithms of the heights. Deviations from logarithmic variation were less than $10 \%$ as long as the wind-speed at $2.8 \mathrm{~m}$ was below $6.1 \mathrm{~m} \mathrm{~s}^{-1}$. Since the mean summer wind-speed was only $3.8 \mathrm{~m} \mathrm{~s}^{-1}$ and mean daily wind-speed exceeded $6.1 \mathrm{~m} \mathrm{~s}^{-1}$ on only $15 \%$ of the days, the general assumption of logarithmic wind profiles seemed justified. The variation of wind-speed with height can be approximated (Holmgren, 1971, p. 5) by:

$$
u=\frac{u_{\star}}{k} \ln \frac{z+z_{0}}{z_{0}}
$$


where $u_{\star}$ is the friction velocity $(\sqrt{\tau / \rho}), k$ is von Kármán's constant $(=0.40)$, and $z_{0}$ is a logarithmic scaling length or surface roughness parameter for wind.

The thermal influence of Hodges Glacier on the overlying air created mildly stable stratifications with a mean lapse of $3 \mathrm{deg}$ through the lowest metre during the summer. The predominance of logarithmic wind profiles suggested such stability did not significantly suppress turbulence (Sellers, [ $\left.{ }^{\mathrm{C}} 1965\right]$, p. 152) and the assumption of equal diffusivities for heat, water vapour, and momentum therefore seemed plausible. Equations (5) and (6) then give

$$
A_{\mathrm{m}}=A_{\mathrm{h}}=A_{1}=u_{\star} k\left(z+z_{\mathrm{o}}\right) .
$$

If logarithmic profiles are also assumed for temperature and water-vapour pressure, Equations (3) and (4) become (Holmgren, 1971, p. 12)

$$
F_{\mathrm{h}}=\frac{\rho C_{\mathrm{p}} k^{2} u\left(T-T_{\mathrm{o}}\right)}{\ln \left\{\left(z+z_{\mathrm{o}}\right) / z_{\mathrm{o}}\right\} \ln \left\{\left(z+r_{\mathrm{o}}\right) / r_{\mathrm{o}}\right\}}
$$

and

$$
F_{1}=\frac{k^{2} L M u\left(e-e_{\mathrm{o}}\right)}{R T_{\mathrm{m}} \ln \left\{\left(z+z_{\mathrm{o}}\right) / z_{\mathrm{o}}\right\} \ln \left\{\left(z+s_{\mathrm{o}}\right) / s_{\mathrm{o}}\right\}}
$$

where $T_{\mathrm{o}}$ is the temperature of the ice surface, $T_{\mathrm{m}}$ the average temperature of the air layer, $e_{\mathrm{o}}$ the water-vapour pressure at the ice surface, and $r_{\mathrm{o}}$ and $s_{0}$ the logarithmic scaling lengths, or surface roughness parameters, for temperature and water-vapour pressure, respectively.

Munro and Davies (1977) have shown that the lowest metre of air over a melting glacier reliably forms a boundary layer where near-logarithmic profiles prevail. Wind-speeds from $1.0 \mathrm{~m}$ and $0.2 \mathrm{~m}$ were therefore used to compute daily values of $\ln z_{\mathrm{o}}$ from Equation (6) during the $17 \mathrm{~d}$ study in December and January. The logarithmic mean value of $z_{\mathrm{o}}$ was $(1.33 \pm 0.25) \times 10^{-3} \mathrm{~m}$ where the uncertainty is estimated from the standard error of the logarithmic mean. This result compares well with those tabulated by Kuhn (1979) for six melting glaciers five of which had values of $z_{\mathrm{o}}$ in the range $(1.1-2.0) \times 10^{-3} \mathrm{~m}$.

For most of the summer, the meteorological site was not surrounded by a uniform surface of snow, firn, or ice. The temporary snow-line and/or the firn-ice boundary generally lay within the equilibration distance for airflows reaching the site (within c. $100 \mathrm{~m}$, Sellers, [ $\left.{ }^{\mathrm{c}} 1965\right]$, p. 147). Down-glacier winds arrived at the site over surfaces where snow predominated, whereas upglacier winds arrived over surfaces where ice predominated. Thus, the mean surface roughness during the $17 \mathrm{~d}$ study reflects the distribution and development of a variety of surface conditions around the site. The variety was believed to be representative of the glacier during summer, and the mean surface roughness was therefore used to estimate aerodynamic heat fluxes throughout the melt season. On small cirque glaciers, it seems inappropriate to associate summer roughness parameters with a single surface type.

Profiles of temperature and water-vapour pressure were not available from Hodges Glacier to determine the corresponding roughness parameters $r_{\mathrm{o}}$ and $s_{\mathrm{o}}$. The identity of $r_{\mathrm{o}}, s_{\mathrm{o}}$, and $z_{\mathrm{o}}$ is assumed in some glacier models (Streten and Wendler, 1968; Kuhn, 1979) but Holmgren (1971) has plausibly argued the identity of $r_{\mathrm{o}}$ and $s_{\mathrm{o}}$ alone. He reviewed values of $r_{\mathrm{o}}, s_{\mathrm{o}}$, and $z_{\mathrm{o}}$ from profiles measured over melting glaciers in Devon Island, Spitsbergen, and Greenland. The values of $z_{\mathrm{o}}$ lay in the narrow range $(1-3) \times 10^{-3} \mathrm{~m}$, whereas $r_{\mathrm{o}}$ and $s_{\mathrm{o}}$ ranged broadly from $(0.3-10) \times$ $10^{-5} \mathrm{~m}$. Since the value of $z_{\mathrm{o}}$ from Hodges Glacier $\left(1.33 \times 10^{-3} \mathrm{~m}\right)$ appeared typical, it was 
anticipated that values of $r_{\mathrm{o}}$ and $s_{\mathrm{o}}$ would also fall within the corresponding range reported by Holmgren. From his review, it was estimated that, to the nearest order of magnitude, $r_{\mathrm{o}}=s_{0}=$ $10^{-5} \mathrm{~m}$. (This was also Holmgren's own best value from his extensive measurements in Devon Island.) The fluxes of sensible and latent heat for melting conditions at the pressure altitude of the meteorological site ( 950 mbar) then become, from Equations (7) and (8)

$$
F_{\mathrm{h}}=2.51 u_{1} t_{1} \mathrm{~W} \mathrm{~m}^{-2}
$$

and

$$
F_{1}=4.03 u_{1}\left(e_{1}-6.1\right) \mathrm{W} \mathrm{m}^{-2}
$$

where $T_{\mathrm{m}}$ was $274.7 \mathrm{~K}$ and $u_{1}, t_{1}$, and $e_{1}$ are the wind-speed $\left(\mathrm{m} \mathrm{s}^{-1}\right)$, air temperature $\left({ }^{\circ} \mathrm{C}\right)$, and water-vapour pressure (mbar) at one metre above the surface, respectively.

Equations (9) and (10) are semi-empirical formulae derived for short-period averages of temperature, wind-speed, and humidity. These variables should exhibit mainly random fluctuations during each averaging period which should therefore be short enough to exclude coupling effects such as the parallel diurnal variation of wind with temperature and water-vapour pressure. In practice, the maximum averaging period which satisfies this criterion is about 60 min (Sellers, [c1965], p. 144). The influence of coupling over periods of one day was examined through an "index of coupling", $\boldsymbol{P}$. This was the ratio of the sum of hourly sensible heat fluxes to the sum of fluxes computed from daily means of the meteorological variables. Values of $\boldsymbol{P}$ were calculated thoughout the first half of February 1974, when ablation was at its height. The index of coupling reached $163 \%$ on a day with a föhn wind and on a day with active thermals. On such days, most sensible heat was transferred when wind and temperature peaked simultaneously; their coupling usually lasted only a few hours and was unrepresented in fluxes calculated with daily means. On days without discernible weather trends the index fell as low as $102 \%$. The values of $\boldsymbol{P}$ showed that computations from daily means always underestimated the flux because wind and temperature are, in general, positively correlated. Owing to the very changeable nature of weather on South Georgia, the average values of $\boldsymbol{P}$ consistently approached $114 \%$ for periods of a week or more. This result was used to simplify the evaluation of the sensible heat flux during each budget interval. The flux was calculated by Equation (9) with daily mean values of wind and temperature, and then increased by $14 \%$ to account for the consistent effect of coupling.

The assumption of neutral or mildly stable stratifications up to one metre above the glacier is believed to be valid even during föhn winds because the stabilizing effect of high temperatures is then balanced by vigorous mixing. The meteorological site was over $150 \mathrm{~m}$ from the up-wind glacier edge and so was beyond the likely equilibration distance for the rock-ice boundary (Sellers, [ $\left.{ }^{\mathrm{C}} 1965\right]$, p. 147). However, the deep cirque containing Hodges Glacier is subject to violent rotor winds which may occasionally have advected air to the site by routes other than along the glacier surface. Errors in the estimates of sensible heat flux arose mainly from the assumption of simple turbulent transfer with constant surface roughness, the restriction of temperature measurements to one level, and the simplified treatment of coupling effects. Instrumental precision was not a significant constraint on accuracy. From these considerations, the error in the sensible heat flux was estimated to be $\pm 20 \%$.

The latent-heat fluxes were computed from Equation (10) with daily means of wind and water-vapour pressure. No correction was applied for coupling because error sources were dominated by the uncertainty in calibration of the dew-cell. This caused possible systematic 
errors of $\pm 0.4 \mathrm{deg}$ in the measured dew points and $\pm 0.3 \mathrm{MJ} \mathrm{m}^{-2}$ in the daily totals of latent-heat flux.

\section{The ICE BALANCE}

The ice balance of a glacier may be expressed in the form (cf. [International Hydrological Decade], 1970)

$$
I_{\mathrm{p}}+I_{1}+I_{\mathrm{f}}=I_{\mathrm{r}}+I_{\mathrm{m}}+I_{\mathrm{s}}
$$

where $I_{\mathrm{p}}$ is the ice gained from solid precipitation, $I_{1}$ the ice gained from condensation processes, $I_{\mathrm{f}}$ the ice gained from freezing of water, $I_{\mathrm{r}}$ the ice lost due to drifting, calving, avalanching, etc., $I_{\mathrm{m}}$ the ice lost due to melting, and $I_{\mathrm{s}}$ the change in ice storage. Calving does not occur on Hodges Glacier and no avalanches were observed at the meteorological site during the period of observation. Drifting was negligible for most of the summer because the snow was quickly metamorphized into a dense granular form. For these reasons, $I_{\mathrm{r}}$ played an insignificant role in the ice balance. Also, because the glacier was at its melting point, $I_{\mathrm{f}}$ was small. $I_{1}$ was discounted because the net exchange of latent heat was small and the associated transport of ice was negligible. Thus Equation (11) can be simplified to

$$
I_{\mathrm{p}}-I_{\mathrm{s}}=I_{\mathrm{m}} .
$$

The net summer budgets at the eight glacier stakes varied randomly by $10 \%$ around an overall linear dependence on altitude. This dependence showed that the net change in ice storage at the meteorological site $(375 \mathrm{~m})$ was $10 \%$ larger than that at the mid-altitude of the stakes $(390 \mathrm{~m})$. For each budget interval, the mean of the storage changes at the stakes was increased by $10 \%$ to extrapolate it to $375 \mathrm{~m}$. The adjusted changes in ice storage were then compatible with heat balances determined at the meteorological site for the same periods and had an estimated uncertainty of $\pm 10 \%$.

\section{Results}

\section{Summer heat and ice balances}

Daily values of the radiative, sensible, and latent-heat fluxes were computed for the summer period of $155 \mathrm{~d}$. Table III lists the components of the heat balance. Radiation supplied $(54 \pm 6) \%$ of the heat income while the remaining $(46 \pm 6) \%$ came as sensible heat. The net loss of latent heat was insignificant. Almost all the heat income was available to melt ice. The mean summer albedo $(=0.54)$ was probably lower than usual because ice would be exposed relatively early in such a warm melt season.

The reduction of insolation by slope and screening at the meteorological site was studied by the method of Garnier and Ohmura (1968). The daily direct insolation on the glacier surface under clear skies was compared with that on an unscreened plateau at the same latitude (Fig. 4). During summer, the deficit ranges from $40 \%$ at the equinox to $10 \%$ at the solstice; for the melt season (November-March) it averages $25 \%$.

The principal components of the ice balance are shown in Table IV together with the melt determined from the heat balance. The ablation of summer snowfalls accounted for $(7 \pm 3) \%$ of 
TABle III. Summer heAt Balance, Hodges Glacier

1 NOVEMBER 1973-4 APrIL 1974 (155 d)

\begin{abstract}
Global short-wave radiation Diffuse short-wave radiation Reflected short-wave radiation

* Net long-wave radiation

Radiative heat income

Sensible heat income

Latent heat income
\end{abstract}

Heat available for melting $F_{\mathrm{m}}$

\begin{tabular}{|c|c|}
\hline $\begin{array}{l}\text { Summer total } \\
\qquad \mathrm{MJ} \mathrm{m}^{-2}\end{array}$ & $\begin{array}{l}\text { Mean daily }{ }^{\dagger} \\
\mathrm{MJ} \mathrm{m}^{-2} \mathrm{~d}^{-1}\end{array}$ \\
\hline $2522 \pm 5 \%$ & 16.3 \\
\hline $1275 \pm 10 \%$ & 8.2 \\
\hline $\begin{array}{l}-1367 \pm \quad 5 \% \\
-521\end{array}$ & $\begin{array}{l}-8.8 \\
-3.4\end{array}$ \\
\hline $634 \pm 15 \%$ & 4.1 \\
\hline $551 \pm 20 \%$ & 3.6 \\
\hline$-31 \pm 150 \%$ & -0.2 \\
\hline $1154 \pm 13 \%$ & 7.4 \\
\hline
\end{tabular}

* Derived as a residual in the radiation balance.

+ Computed from summer totals.

the observed melt; wastage of winter snow, firn, and glacier ice accounted for the remaining $(93 \pm 3) \%$. The melt computed from the heat balance was only $2 \%$ greater than the observed melt, the small difference being well within the estimated errors.

\section{Heat and ice balances of the budget intervals}

The effect of albedo changes and föhn winds on the radiative and sensible heat fluxes was studied by dividing the melt season according to periods of high albedo (intervals I-VI), intermediate albedo (VII-VIII), and low albedo (IX-XV). For each period Table V shows the surface albedo, the incidence of föhn winds, the heat fluxes, and their ratio. Corresponding data are also shown for the entire summer.

The surface albedo of the glacier decreased consistently as firn and then ice were exposed by summer melting. Radiative heating was greatest during the period of intermediate albedos occurring 2-4 weeks after the summer solstice. The heating was about $50 \%$ less during the initial

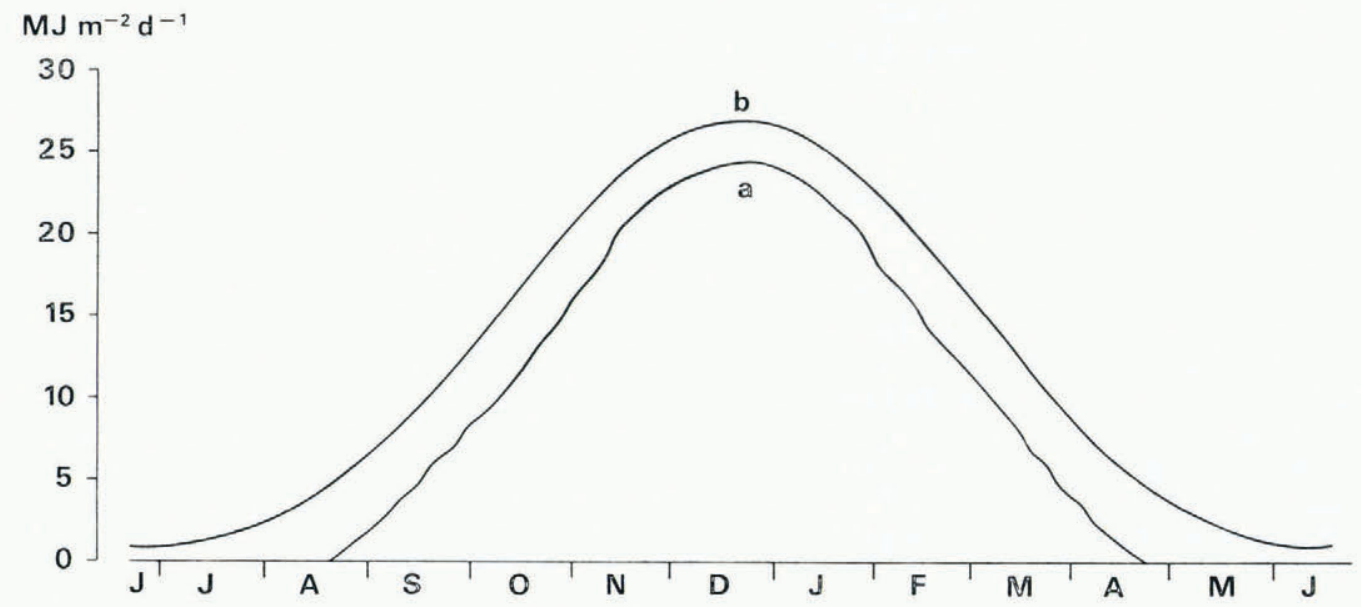

Fig. 4. Daily direct insolation under clear skies at (a) the meteorological site on Hodges Glacier and at (b) an unscreened plateau in the same latitude. 
Table IV. Summer ice balance, Hodges Glacier meteorological site, 1 NOVEMBER 1973-4 APRIL 1974

$\begin{array}{llr} & & \mathrm{m} \mathrm{H}_{2} \mathrm{O} \\ \text { Change in ice storage } & I_{\mathrm{s}} & -3.12 \pm 10 \% \\ \text { Snowfall } & I_{\mathrm{p}} & +0.25 \pm 20 \% \\ \text { Melt } & I_{\mathrm{m}}=I_{\mathrm{p}}-I_{\mathrm{s}} & 3.37 \pm 9 \% \\ \text { Melt from heat balance } & F_{\mathrm{m}} & 3.45 \pm 13 \%\end{array}$

high-albedo period, and about $20 \%$ less during the period of low albedos towards the end of summer. The latter reduction arose from enhanced mountain screening as the sun's declination moved northwards (Fig. 4) and not from an increase in cloud cover (Fig. 3).

Föhn winds were most frequent and intense during the final period of low surface albedos. Sensible heating was then more than twice that during the earlier periods. Although there were no föhn winds during the period of intermediate albedos, sensible heating was greater than during the initial period (when there were three föhn winds) because air temperatures were generally higher (Fig. 3).

The relative importance of radiative and sensible heating was calculated for each period by the ratio $F_{\mathrm{r}}: F_{\mathrm{h}}$. During the first period, radiative heating was limited by the high albedo but still predominated over sensible heating, which was heavily constrained by the low temperatures and the infrequency of fön winds. During the second period radiation was the dominant heat source because albedos were lower and there were no föhn winds to augment sensible heating. During the final period the high incidence of fön winds caused sensible heating to predominate, even though radiative heating was sustained by the low surface albedo. The variations in $F_{\mathrm{r}}: F_{\mathrm{h}}$ (Table V) reflect changes in the incidence of föhn winds rather than the development of lower surface albedos during summer. This is true in spite of the fact that the three periods were defined by albedo regime.

The effect of föhn winds in controlling the summer heat partition on Hodges Glacier can be shown for budget intervals as well as for periods of differing albedo. During the intervals in which föhn winds occurred, the ratio $F_{\mathrm{r}}: F_{\mathrm{h}}$ had an average value of $47: 53$, whereas, in intervals without them, the average value was $63: 37$.

The greatest rate of melting occurred during interval IX when ice surfaces of low albedo enhanced radiative heating and two föhn winds brought rapid transfers of sensible heat (Fig. 5a

TABLE V. FACTORS AFFECTING THE RADIATIVE AND SENSIBLE HEAT FLUXES

\begin{tabular}{|c|c|c|c|c|c|c|c|}
\hline $\begin{array}{l}\text { Period } \\
1973-74\end{array}$ & mean & $\begin{array}{l}\text { Albedo } \\
\text { range }{ }^{\dagger}\end{array}$ & $\frac{F_{\mathrm{r}}}{\mathrm{MJ} \mathrm{m}}$ & $\begin{array}{l}\text { No of } \\
\text { mild* }\end{array}$ & $\begin{array}{l}\text { in winds } \\
\text { severe** }\end{array}$ & $\frac{F_{\mathrm{h}}}{\mathrm{MJ} \mathrm{m}^{-2} \mathrm{~d}^{-1}}$ & $F_{\mathrm{r}}: F_{\mathrm{h}}$ \\
\hline $\begin{array}{l}1 \text { November-7 January } \\
\text { (budget intervals I-VI) }\end{array}$ & 0.67 & $0.60-0.73$ & 3.0 & 3 & 0 & 1.9 & $62: 38$ \\
\hline $\begin{array}{l}\text { 8-24 January } \\
\text { (budget intervals VII-VIII) }\end{array}$ & 0.54 & $0.50-0.57$ & 5.9 & 0 & 0 & 2.6 & $70: 30$ \\
\hline $\begin{array}{l}25 \text { January- } 4 \text { April } \\
\text { (budget intervals IX-XV) }\end{array}$ & 0.34 & $0.28-0.44$ & 4.7 & 5 & 6 & 5.4 & $46: 54$ \\
\hline $\begin{array}{l}1 \text { November-4 April } \\
\text { (summer) }\end{array}$ & 0.54 & $0.28-0.73$ & 4.1 & 8 & 6 & 3.6 & $54: 46$ \\
\hline
\end{tabular}




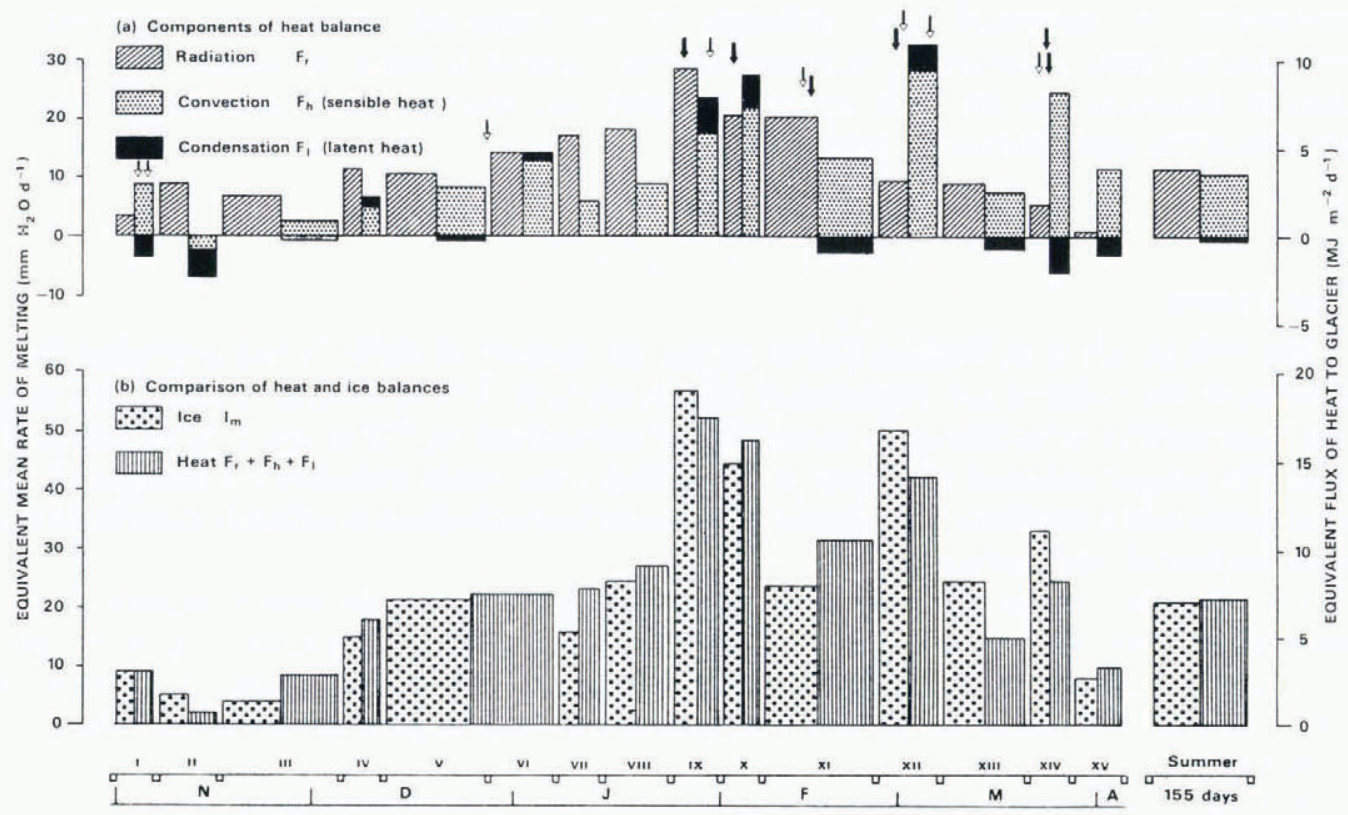

Fig. 5. Components of heat balance (a) and comparison of heat and ice balances (b) at the meteorological site on Hodges Glacier. Components and balances are both shown for 15 budget intervals (I-XV) and for the entire summer I November 1973 to 4 April 1974. Intervals $V$ and VI are combined in (b) - see text. A rrows (a) denote days with vigorous föhn winds as: $\nabla$ föhn with $15^{\circ} \mathrm{C}>$ maximum air temperature $>10^{\circ} \mathrm{C}$ and relative humidity $<60 \%, \downarrow$ föhn with $20^{\circ} \mathrm{C}>$ maximum air temperature $>15{ }^{\circ} \mathrm{C}$ and relative humidity $<60 \%$.

and b). Melting was slowest during interval II when air temperatures were generally below $0{ }^{\circ} \mathrm{C}$ (Fig. 3) and most of the available heat was used for evaporation. Interval II was the only period in which convection failed to contribute heat for melting.

Although latent-heat fluxes were generally insignificant, the results suggested (Fig. 5a) that there was net evaporation in early and late summer when water-vapour pressure was relatively low (Fig. 3). In mid-season, however, as water-vapour pressures rose, condensation prevailed and became pronounced during intervals IX, X and XII, when föhn winds were particularly active.

For most intervals there was broad agreement between the heat and ice balances (Fig. 5b). For ease of analysis, heat balance intervals began and ended at midnight but ice balance intervals were defined by stake measurements made during daytime. The differences in scheduling $(c .12 \mathrm{~h})$ were short in relation to the length of each interval (6-21 d) and only once caused a significant error. This was on 28 December when a vigorous föhn wind occurred between the end of heat balance interval V (midnight on 27 December) and the end of the corresponding ice balance interval (afternoon of 28 December). In this case, scheduling errors were eliminated by combining intervals V and VI for comparison of heat and ice balances.

The differences between the heat and ice balances in each interval gave no indication that any component of the heat-balance estimates was a predominant source of error. The overall agreement was $11 \%$ for intervals III-X when melting temperatures prevailed and the meteorological site was fully instrumented. Thereafter, the site was gradually dismantled and the 
deterioration in agreement was attributed to an increasing reliance on extrapolated meteorological data. Although the agreement between summer balances was within $2 \%$, this was probably fortuitous and the $11 \%$ agreement found over intervals III-X is considered more indicative of the general accuracy attained.

\section{CONCLUSIONS}

The melt at $375 \mathrm{~m}$ on Hodges Glacier during the summer of 1973-74 was computed from estimates of the radiative and atmospheric heat fluxes to be $3.45( \pm 13 \%) \mathrm{m}$ of water. The melt from observations at neighbouring budget stakes extrapolated to $375 \mathrm{~m}$ was $3.37( \pm 9 \%) \mathrm{m}$ of water. The glacier remained effectively at the melting point, which simplified the comparison of summer heat and ice budgets. The absence of a glacier heat-storage term probably contributed to their close numerical agreement.

The preceding winter was one of average accumulation and the winter balance at the meteorological site was equivalent to $0.94 \mathrm{~m}$ of water. The summer was abnormally warm and sunny, and the annual net ice budget at the meteorological site was equivalent to $-2.43 \mathrm{~m}$ of water. The melt was considered to be greater than average and, in general, this budget is likely to be less negative.

Radiative heat contributed $54 \%$ of the heat income while the remaining $46 \%$ came as sensible heat. The net flux of latent heat was insignificant. The radiative contribution was probably enhanced by an early exposure of ice surfaces during this unusually warm summer. It is suggested that, in more typical summers, radiative and sensible heat are of more equal importance, with the possibility that following winters of heavy accumulation the sensible heat may exceed the radiative heat.

A previous study on Hodges Glacier suggested that radiation, sensible heat, and latent heat contributed equally to the heat balance at about $360 \mathrm{~m}$ (Smith, 1960). However, the radiative flux was then estimated from empirical formulae and from assumed values of albedo, while the flux of latent heat was evaluated with data extrapolated from sea-level. In the light of the more direct results now available, Smith's partition of the heat balance appears misleading. To within $5 \%$, the balance is:

radiation $55 \%$, convection $45 \%$, condensation $0 \%$.

Andrews ([ $\left.{ }^{c} 1975\right]$, figure 2-5 A) has classified glaciers in three broad groups according to the partitions of their summer heat balances. The glaciers of group I are those where radiation dominates $(>65 \%)$ and are found mainly at high altitudes and high latitudes. Group III represents the opposite extreme of glaciers where radiation supplies less than $36 \%$ of the heat balance; they occur mainly in coastal high latitudes. The glaciers of group II fall between these limiting cases $(65 \%>$ radiation $>36 \%)$ and are geographically diverse. Smith's partition suggested that Hodges Glacier belonged to group III; our measurements now indicate that it belongs to group II. This is at first surprising as a glacier in South Georgia would seem an ideal candidate for classification with those of the coastal high latitudes. However, maritime influences are greatest on the windward flank of the Allardyce Range where frequent orographic cloud impedes radiative heating. Hodges Glacier lies in the lee of the mountains where skies are clearer and radiation is relatively more important, despite the enhanced convection during föhn winds. The glacier is only two kilometres from the sea, yet, by the influence of regional topography, it 
escapes the coastal high-latitude classification of group III. The partition of its heat balance is common to the wide variety of glaciers in group II.

Hodges Glacier is the largest ice mass on the peninsula between Cumberland East Bay and Cumberland West Bay. The glacier's slope and cirque situation constrain summer ablation by reducing the possible direct insolation to about $75 \%$ of that on anscreened ice cap.

\section{ACKNOWLEDGEMENTS}

This work was funded jointly by the British Antarctic Survey and the Institute of Hydrology as a contribution to the International Hydrological Decade. Logistic support was given by the British Antarctic Survey and by the helicopters of H.M.S. Endurance. Dr C. W. M. Swithinbank of the British Antarctic Survey and Dr J. S. G. McCulloch of the Institute of Hydrology guided the project and their staff gave valuable assistance. In particular, R. C. Hayward, A. W. Jamieson, N. J. Sheppard, and Dr K. A. Edwards participated in the field work and Dr C. S. M. Doake, B. G. Gardiner, and Dr D. A. Peel made helpful criticisms during preparation of the manuscript.

MS. received 2 December 1980 and in revised form 15 June 1981

\section{REFERENCES}

Andrews, J. T. [ $\left.{ }^{c} 1975.\right]$ Glacial systems. An approach to glaciers and their environments. North Scituate, Mass., Duxbury Press. (Environmental Systems Series.)

British Antarctic Survey Meteorological Service. Unpublished. Annual meteorological tables for 1964-1970.

Garnier, B. J., and Ohmura, A. 1968. A method of calculating the direct shortwave radiation income of slopes. Journal of Applied Meteorology, Vol. 7, No. 5, p. 796-800.

Gilbert, O., and others. 1969. Regime of an Afghan glacier, by O. Gilbert, D. Jamieson, H. Lister, and A. Pendlington. Journal of Glaciology, Vol. 8, No. 52, p. 51-65.

Grainger, M. E., and Lister, H. 1966. Wind speed, stability, and eddy viscosity over melting ice surfaces. Journal of Glaciology, Vol. 6, No. 43, p. 101-27.

Holmgren, B. 1971. Climate and energy exchange on a sub-polar ice cap in summer. Arctic Institute of North America Devon Island Expedition, 1961-63. Pt. D. On the vertical turbulent fluxes of water vapour at ice cap station. Meddelanden frản Uppsala Universitets Meteorologiska Institution, Nr. 110.

[International Hydrological Decade.] 1970. Combined heat, ice, and water balances at selected glacier basins: a guide for compilation and assemblage of data for glacier mass balance measurements. Paris, UNESCO/IASH. (Technical Papers in Hydrology, 5.)

Kondratyev, K. Ya. 1969. Radiation in the atmosphere. New York, Academic Press. (International Geophysics Series, Vol. 12.)

Kuhn, M. 1979. On the computation of heat transfer coefficients from energy-balance gradients on a glacier. Journal of Glaciology, Vol. 22, No. 87, p. 263-72.

Latimer, J. R. 1963. The accuracy of total radiometers. Canada. National Research Council. Associate Committee on Soil and Snow Mechanics. Technical Memorandum No. 78, p. 31-67.

Limbert, D. W. S. 1977[a]. Climatological summary for 1973. British Antarctic Survey Bulletin, No. 45, p. $131-37$.

Limbert, D. W. S. 1977[b]. Climatological summary for 1974. British Antarctic Survey Bulletin, No. 45, p. 139-45.

Limbert, D. W. S., and Loan, R. S. B. 1976[a]. Climatological summary for 1971. British Antarctic Survey Bulletin, No. 44 , p. $31-37$.

Limbert, D. W. S., and Loan, R. S. B. 1976[b]. Climatological summary for 1972. British Antarctic Survey Bulletin, No. 44 , p. $39-45$.

Mansfield, A. W., and Glassey, S. D. 1957. Notes on weather analysis in the Falkland Islands Dependencies, Antarctica. Falkland Islands Dependencies Survey. Scientific Reports, No. 16. 
Martin, S. 1975. Wind regimes and heat exchange on glacier de Saint-Sorlin. Journal of Glaciology, Vol. 14, No. 70, p. $91-105$.

Munro, D S., and Davies, J. A. 1977. An experimental study of the glacier boundary layer over melting ice. Journal of Glaciology, Vol. 18, No. 80, p. 425-36.

Paterson, W. S. B. 1969. The physics of glaciers. Oxford, etc., Pergamon Press. (The Commonwealth and International Library. Geophysics Division.)

Sellers, W. D. [ $\left.{ }^{c} 1965.\right]$ Physical climatology. Chicago and London, University of Chicago Press.

Smith, J. 1960. Glacier problems in South Georgia. Journal of Glaciology, Vol. 3, No. 28, p. 705-14.

Stansbury, M. J. Unpublished. Glaciological observations in South Georgia, 1958. [Falkland Islands Dependencies Survey. Preliminary Glaciological Report No. 3.]

Streten, N. A., and Wendler, G. 1968. The midsummer heat balance of an Alaskan maritime glacier. Journal of Glaciology, Vol. 7, No. 51, p. 431-40.

Sutton, G. A. 1957. Glacier island: the official account of the British South Georgia Expedition 1954-1955. London. Chatto and Windus.

Williams, L. D. 1974. Computer simulation of glacier mass balance throughout an ablation season. Proceedings of the Western Snow Conference, 42nd annual meeting, p. 23-28.

[World Meteorological Organization.] 1970. Guide to hydrometeorological practices. Second edition. Geneva, World Meteorological Organization. (WMO-No. 168, TP. 82.) 